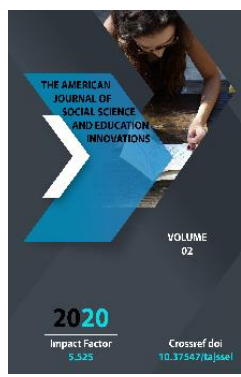

\title{
Dynamics Of Moral Relations In Uzbekistan: Social And Philosophical Aspect
}

\author{
Khakimov Erkin \\ Candidate Of Philosophical Sciences, Associate Professor, Ferghana State University, \\ Uzbekistan
}

\section{ABSTRACT}

The article is dedicated to the problems of transformation of morality relations in Uzbekistan after gaining independence. The goals and objectives are to analyze and identify the main trends in the development of moral relations in Uzbekistan. The work aims to show main factors influencing this process. This is relevant for the reason that the success of reforms depends on these trends and their consideration in the process of reforming society, since the role of the subjective factor, that is, the people who carry out these reforms is very great. The dynamics of the socio-economic conditions of the life of people causes the transformation of the system of values that was fixed in the spiritual culture, and the moral relations that have developed in society. The "old" values are replaced by "new" ones and a new configuration of their subordination is being built.

\section{KEYWORDS}

Morality, moral relations, spirituality, moral values, market relations, national traditions, transformation, contradictions of moral values, a layers within moral relations, political factors, ideology.

\section{INTRODUCTION}

The modern stage of development of Uzbekistan is characterized by the formation of new forms of public relations. This is determined by a number of factors, both external and internal, both objective and subjective, the most important of which are the changes taking place in the modern world, as well as the gaining of independence by Uzbekistan. (The dynamic transformation of all spheres of public life during the period of 
reforms in independent Uzbekistan affected the sphere of moral relations.) The transformation of moral relations seems to be lagging behind and the development trends in this sphere have yet to be identified and comprehended.

It is necessary to comprehend the new realities in this sphere through the prism of strategic goals and objectives declared in the work of the First President of Uzbekistan "High spirituality is an invincible force" [1]

The author believes that for deep thorough study of morality problems, for their translation into a practical plane, in order to avoid the invocative declarative character, today serious joint efforts of ethnopsychologists, sociologists and philosophers are needed. Apparently, today the problem of morality is just such an interdisciplinary problem that requires collective efforts of scientists to avoid scholastic theorizing and overcome the anthropological crisis. These global tendencies in the formation of new social relations, as well as the fact that Uzbekistan is developing in the conditions of independence, have necessitated a new paradigm for the study of moral relations. [2 ]. First, the emergence (entry into the practice of morality) of new forms of relationship as a synthesis of the traditional and the new is a result caused by changes in the economic sphere, which is inevitably reflected in the sphere of morality. Moreover, the traditional inertia can be understood, in particular, as the antithesis of the Soviet past (international) and the new as national (reanimating, reviving in conditions of independence). Another possible antithesis of the traditional, as a set of principles of Islamic morality, and the new, as a set of secular principles of moral consciousness and behavior. As a result, various forms of morality function in society of Uzbekistan. First, the morality, which is carried by the representatives of the older generation people of predominantly retirement age or those close to it. This morality is characterized by elements of what is commonly called "socialist morality". The basis of such morality was the "code of the builder of communism," which was based on socialist public ownership of the means of production. This type of property demanded and "cultivated" in the field of morality such principles as: collectivism, comradely mutual assistance, disregard for personal goals in the name of public, modesty in everything, limited desires, dominance of spiritual and ideological values. A significant part of this age group is also characterized by an orientation towards many elements (as a result of the rejection of past moral norms) of "Islamic morality", especially in the domestic and family spheres. Until recently, this form of morality was dominant in society, since its carriers were the most socially active part of society. It is also a way of national selfidentification and spiritual self-expression. Spirituality in the East has always had a mystical trail, religious and idealistic overtones. [ 3 ]. Secondly, as a result of development in conditions of independence and the change in the ideological and economic foundations (guidelines) of society, significant changes occur in the sphere of moral relations. This is due to the fact that the new economic relations, having confirmed their viability and greater efficiency in the new economic realities, give rise to a new system of values and strengthen the role and importance of moral norms adequate to them.

In passing, we note that the growing interest in Islamic morality throughout the world is quite 
justified. For example, according to the British media, the Islamic community in England is the second largest. The constructive dialogue between the West and the East in the field of morality is being actualized as a means of overcoming the moral impasse, the anthropological crisis, in which a society oriented only towards the consumption of material goods finds itself. The transformation of Islam in the context of the globalizing world and Islamic morality as an important component of it is a topic for a separate special study. But as a factor of development - in a certain sense as a "storehouse of moral commandments" - of universal human morality, it becomes more and more significant in Uzbekistan.[4].

\section{LITERATURE REVIEW}

A dominant form of morality is characteristic of each specific period in the development of society. It is characterized by the functioning of simple moral norms in it, conditioned by national moral traditions, as well as by that part of it that depends on socio-economic and political conditions. All these factors are interconnected and interdependent and constitute a new integrity, the functioning of which causes transformation or even deformation of morality. So, for example, "Western European" rationalism, individualism and egoism seem to be the opposite of "Eastern" mysticism, irrationalism and nepotism. The rather "tough" relatively stable system of moral norms of the Soviet period has been replaced today by the "open" dynamically democratizing liberal moral system. Moral relations, first of all, are a system of values that is consolidated and maintained in society. They act as a single internally organized system of links between norms and prohibitions. As is known, moral relations are always especially significant relationships between people, that value framework of their social ties, which is fixed in morals, determines their well-being and understanding of the meaning of their being. Relations in the field of morality are canons that govern behavior and the transmission of moral experience. The moral relations existing in society act as a matrix of value values with its inherent hierarchy and interdependence. The interactions between different value values lead to a "reset of the moral matrix." The dynamics of the socio-economic conditions of the life of people causes the transformation of the system of values that was fixed in the spiritual culture, and the moral relations that have developed in society. The "old" values are replaced by "new" ones and a new configuration of their subordination is being built. In the system of moral relations, in our opinion, the following structural and substantive moments can be distinguished:

- The layer of the universal, which includes the value of life, health, motherhood, marriage, respect for parents, caring for children, such moral universals as mercy, compassion, etc.;

- A layer of national and confessional, which contains something special, namely: norms governing the household, family sphere, gender relations, demographic groups, etc.;

- A layer that depends on socio-economic grounds: regulating the attitude, in particular, to various types of property, forms of exchange, consumption and distribution, and, in general, the relationship in the production and professional sphere ;

- A layer, associated with the political and ideological sphere: attitudes to political 
values, ideals and goals, ideological postulates, moral assessment of the activities of power structures (public, official and unspoken, private), etc.

Principles, norms and rules of behavior declared by public morality, as well as examples of a proper "correct" life and ideals as guidelines and incentives for further development, act as moral values. Based on the established system of values in society, the human consciousness receives a constant opportunity to assess the behavior and actions of individuals and social groups.

Moral values "permeate" the entire spiritual culture of society. They are reflected in philosophical concepts, refracted in works of art, proclaimed as the goals of the educational process, and internalized through the way of life and experiences of people. The processes of interiorization are so diverse in the conditions of pluralism of people's lifestyles and the polyphony of their value orientations that it is not necessary to speak of monomorality, of a single understanding of morality. Thus, the liberalization of economic relations, in particular, and the democratization of social relations in general, determine a certain hierarchy and pluralism of moral norms.

Along with the system of values, moral relations include replicated (cult, popularized) "styles" of life, stereotypes of behavior of social groups that have become traditions and rules of etiquette. Basically, the rules of modern etiquette are universal, since they are observed by representatives of the most diverse socio-political systems that exist in the modern world. The peoples of each country make their own amendments and additions to etiquette, conditioned by national traditions and customs. There are several types of modern etiquette, the main of which are: diplomatic etiquette, military etiquette, general civil etiquette. They also include themselves channels of information about moral norms, ways to achieve them, broadcasting moral experience from generation to generation.

In the conditions of the information explosion, when various information flows "cover" the lodges, sometimes not giving the opportunity to deeply comprehend them, it is difficult for a person to determine his own moral position due to the lack of time and the lack of the need for moral self-reflection. Moral relations are characterized by the presence of standards, non-compliance with which leads to social sanctions (approval or condemnation, prohibition or permission) that regulate the degree of morality in people's behavior.

The author considers it necessary to have a brief excursion into the specifics of moral relations in order to clarify the inertia manifested in the moral consciousness of a part of our society. The point is that the market economy forms moral norms that are in many ways contrary to the moral norms of an "ideal" society in which social and state ownership of the means of production prevails. This thought in all possible ways throughout the life of several generations was "introduced" in the minds of the masses.

The market economy at the initial stage of the transition period and the moral norms that it forms are quite often perceived by a certain part of the population as unfair due to a number of objective and subjective reasons:

a) transformation of ideas about social justice,

6) falling living standards and low living standards of most significant gap in the level of 
income and in the level and quality of life of the population ,

c) the stratification of society and the presence of a advantages of a certain category of persons in relation to property in the process of privatization (this could not be avoided in any country where denationalization was carried out economy).

\section{ANALYSIS AND RESULTS}

In many ways, the reasons that cause moral criticism of a number of social processes and phenomena are objective in nature, they are inevitable in the transition period, since the formation of market relations nowhere and has never been problem-free and painless and necessarily leads to social stratification. This stratification is mainly based on subjective and situational factors. This is what causes active rejection of changes in moral consciousness at the initial stage of market reforms as a manifestation of social injustice. However, there is practically no other way of transition from one socio-economic system to another in the world. Therefore, only a change of generations, as well as the highest professional level in the management of society, the rise of the economy, an increase in the standard of living of the broad strata of the population can "soften" the moral assessments of what is happening and lead to the formation of a new moral consciousness of the individual and society. Thus, the contradictory nature of moral norms is a condition for the development of a "new" morality. What measures are needed? The first is understanding the significance of such factor as economic growth, raising living standards, etc. Subjective factors are no less important. It is no coincidence that the political leadership of the Uzbekistan, First President I. Karimov payed great attention to issues of spirituality, development and improvement of the moral sphere and now, President Sh. Mirziyoev continue this line.[5 ]. These measures are aimed at shaping the subject of new social relations. The fact is that from time immemorial in the East in general, and in the Muslim East, in particular, much attention was paid to issues of morality and spirituality. Spirituality in Islamic interpretation is an important and unique component of mentality and it is a special and interesting topic for scientific research. Let us remember that Sharia is the moral and, at the same time, legal system of Islam [ 6 ]. Many existing problems would be solved more effectively, and some would not arise at all if the spiritual and moral level of society (the majority of the population) were much higher. This is not something else as it could automatically entail an increase in social responsibility, an increase in professionalism, a decrease in the level of corruption, crime, and other abuses. Therefore, the five initiatives of the President of Uzbekistan Sh. Mirziyoev are actual and timely. [ 7 ]. It should be noted that in conditions of independent development, the task is to achieve a rise in the spiritual and moral atmosphere of our society.

Successful implementation of reforms depends on the "acquisition" of new qualities by a person, demanded by the ideology of market relations, including the formation of a new worldview and a new moral consciousness as its most important component. The problems touched upon in the article acquire special significance when they are projected onto young people. The spiritual and moral atmosphere in which young people are formed, their values and consciousness, is the atmosphere of a transitional period both in the 
personal individual and in the social dimension. All tendencies of spiritual and moral life characteristic of this time influence the process of formation of the younger generation. Empirical studies indicate that young people capture the leading and promising trends in social development in their minds. Trying to understand them, youth is focused on pragmatism, initiative, the ability to be in demand as a necessary quality of successful self-realization in the new economic realities. This sometimes causes quite conflicting relations between "fathers" and "children" in the sphere of morality. Naturally, young people are "open" to innovations in the practice of moral relations to a much greater extent than older people, who are more conservative and inertial due to their age, social and marital status. We can talk about the originality of the moral consciousness and behavior of young people as a means of selfexpression, sometimes taking quite asocial and immoral forms from the point of view of traditional morality. Young people are a special subject of social development and have the right to their own system of moral values. To overcome the conflict of generations, an interested constructive dialogue is need.

In a market economy, the role of the elements of corporate ethics in the practice of moral relations will increase as a necessary condition for the success of enterprises in an emerging competitive environment. Overall, this is a positive process. However, situations are possible when the principles of corporate ethics contradict the norms and principles of common human morality. So, for example, tough competition on the stock exchange, the desire to overtake professional positions, bankruptcy of enterprises and related administrative decisions, etc.
An important problem that needs to be solved, the need to find a balance between protectionism in the field of personnel (as an inevitable companion of private property) and the need to increase the competitiveness of enterprises in an open economy. In other words, a balance is needed between the desire to have in your environment, at the enterprise, institution employees who can be trusted, who will not betray or deceive, will not steal, etc. and the need to have in the work collective the best highly professional specialists who can allow themselves to be capricious, obstinate, uncomfortable, not relatives, finally, etc. Differentiation of ethical norms due to the differentiation and fragmentation of professional must lead to difficulties in selfdetermination in the moral position of actualization and the need to search for a common positive-constructive basis as a condition for an open tolerant "dialogue" of different positions. The grounds for social optimism in the question of morality are exist. The potential of the moral traditions of the peoples of Central Asia in the formation of spirituality is quite high, since the moral aspect has always been present in social concepts and they were not purely philosophical, educational, legal in nature, but were with the moral epithet: moral-philosophical, moraleducational, moral-legal ... This is evidenced by the works of Al Farabi, Al Beruni, Abu Ali ibn Sino, Imam Bukhari, Imam Yassaviy, Alisher Navoi, etc.[ 8 ].

\section{CONCLUSION/RECOMMENDATIONS}

In the last two decades in Uzbekistan's social science, works dedicated to the problems of the theory of morality and the analysis of moral relations are very rarely published. The publications are mainly devoted to the history of morality, ethical views of thinkers of the 
past, problems of moral education. This is mainly due to the fact that the change in the socio-economic foundations of society required the emergence of a new paradigm for the study of the moral and ethical sphere. A certain period was needed for the manifestation of the tendency in the development of the moral sphere of society. The dual nature of man (when a man is the object and subject of social movement ) complicates these processes, which should have been established. Comprehension of the processes of moral life, determined by new social realities, seems to be late. The author believes that in the moral perspective there will be a harmonization between the national and ethnic features of the functioning of morality with layers that depend on the socio-economic and socio-political foundations.

Moreover, the influence of biomedical ethics, environmental ethics on public consciousness will increase, the professional and ethical sphere will improve, as well as the problems of the relationship between morality and management. Without the active inclusion of moral determinants in the sphere of leadership and management, the functioning of the rule of law and the formation of civil society are impossible. In conditions when there are no dominant established norms that depend on socio-economic coordinates, an orientation towards traditional national oriental morality and universal morality is one of the priorities in the formation of a new morality of independent Uzbekistan, a constructive solution to the antinomy of traditions and the principles of innovation.

\section{REFERENCES}

1. Karimov I.A. "Juksak manavijat-engilmas kuc". Tashkent, 2008.
2. A.Erkaev. Duxovnostb razvitie.Taşkent, 2008.

3. falsafasi East kadrijatlari and ularning Uzbekistan manavij xaetida urni. Tashkent, Tashkent State şarkşunoslik itnstituti, 2009, B.277.293.

4. E.Umarov, M.ABdullaev, E.Xakimov.K ulbturologija, Tashkent, 2004, s.48.

5. Lex.uz.

6. Mavljutov RR Islam, Moscow 1974.s.131.

7. Lex.uz.

8. East falsafasi kadrijatlari and ularning Uzbekistan manavij xaetida urni. Tashkent, Tashkent State şarkşunoslik itnstituti, 2009, B.106,196,265,359.

9. Hakimov, E. T. (2019). Culture of Human B PERIOD SOЦIALbNЫX TRANSFORMAЦIJ: SOЦIALbNO-FILOSOFSKIJ ASPEKT. In Uslovija soцialbno-ekonomiceskogo razvitija Furugh: istorija sovremennostb (pp. 50-53).

10. Mirzaraximov, B. H. (2019). Culture and tourism STRATEGY More RAZVITIJa KNIGOVEDENIJa. InPERSPEKTIVNGIE OBLASTI RAZVITIJa NAUKI of TEXNOLOGIJ (pp. 57-58).

11. Mirzarahimov, B. H. (2020). The Tasks Of Tourism In Aesthetic Education: The Harmony Of Historicity And Modernity. The American Journal of Social Science and Education Innovations,2(09), 652-658.

12. Mirzarahimov, B. (2019). The factor of good neighborhood and tourism development (Philosophical analysis). Scientific Bulletin of Namangan State University, 1(1), 140-145.

13. Mirzarakhimov, B. (2020). Tourism-is a modern means of aesthetic education. СБОРНИК СТАТЕЙ. 